\title{
17 The Roles of Natural and Human Disturbances in Forest Soil Erosion ${ }^{1}$
}

\author{
W.J. Elliot \\ USDA Forest Service Rocky Mountain Research Station, USA
}

\begin{abstract}
Introduction
Forests provide numerous benefits for society, including fibre, wildlife and recreation. Forest managers are challenged to balance ecosystem health with maintaining public forest lands for multiple uses. During the first half of the last century, public forest management emphasized the harvesting of forest resources. In recent years, public forest management goals have shifted to long-term sustainability.

During most of the last century, fire suppression and timber harvest were the main fuel management practices. Timber harvest generally implies the removal of logs that can be processed into lumber. Most timber harvest activities removed almost all of the standing timber, leaving behind smaller trees, diseased trees or undesirable species. Selective harvesting and fire suppression activities have resulted in a surplus of fuels in many forests (Schmidt et al., 2002). These fuels are causing an increase in high-severity wildfires. Fuel management in forests is a new challenge for many agencies to address in the USA. Forest managers are now carrying out practices to reduce this excess fuel, including thinning and prescribed fire. Thinning removes small diameter material, much of which has limited market value. Larger trees are frequently left behind during thinning operations.
\end{abstract}

Soil erosion is another major concern in forest management. In forested watersheds, erosion includes upland surface processes such as rill and interrill erosion, gullying and channel processes, and mass wasting. This paper will focus on surface erosion, and the delivery of that source of sediment to and through stream systems. Fires, timber harvest and roads increase soil erosion and sediment delivery from forest watersheds. Soil erosion reduces forest productivity and eroded sediment may adversely affect water quality in forest streams. Managers are seeking to minimize erosion by applying improved management practices for forestry operations and roads. One of the considerations when seeking to minimize erosion is whether fuel management operations like prescribed fire or thinning (and the associated road network) cause more or less erosion than wildfires. The purpose of this paper is to compare predicted upland erosion rates following forest disturbances associated with fuel management, such as harvesting, thinning, prescribed fire and road networks, to erosion rates following wildfires.

\section{Forest Erosion Processes}

Forest disturbances such as forestry operations and wildfire have major effects on both the vegetation and the soil properties. Soil erodibility

${ }^{1}$ This chapter was written and prepared by a US Government employee on official time, and therefore it is in the public domain and not subject to copyright. 
depends on both the surface cover and the soil texture (Robichaud et al., 1993; Elliot and Hall, 1997). Erodibility following a wildfire is much greater than that in an undisturbed forest (Robichaud et al., 1993). Forests are highly susceptible to erosion in the year following a fire or a forestry operation. Forests do, however, recover quickly as vegetation regrowth is rapid when smaller plants do not have to compete with trees for sunlight, nutrients and water. For example, erosion rates following a wildfire in Eastern Oregon dropped more than $90 \%$ in the first year, with no erosion observed in year 4 (Fig. 17.1).
Erosion in forests is highly variable. In many ecosystems it is driven by a few extreme events each decade, and highly influenced by recent disturbances. Sediment production during years without large runoff events or disturbances are likely to be well below 'average' erosion rates, and the production during a year with a major runoff event or following a major disturbance is likely to be well above the 'average' rate (Kirchner et al., 2001). For example, road erosion is influenced by weather and presence of traffic (Fig. 17.2). In the 4-year study in Fig. 17.2 (Foltz, 1998), there was more than

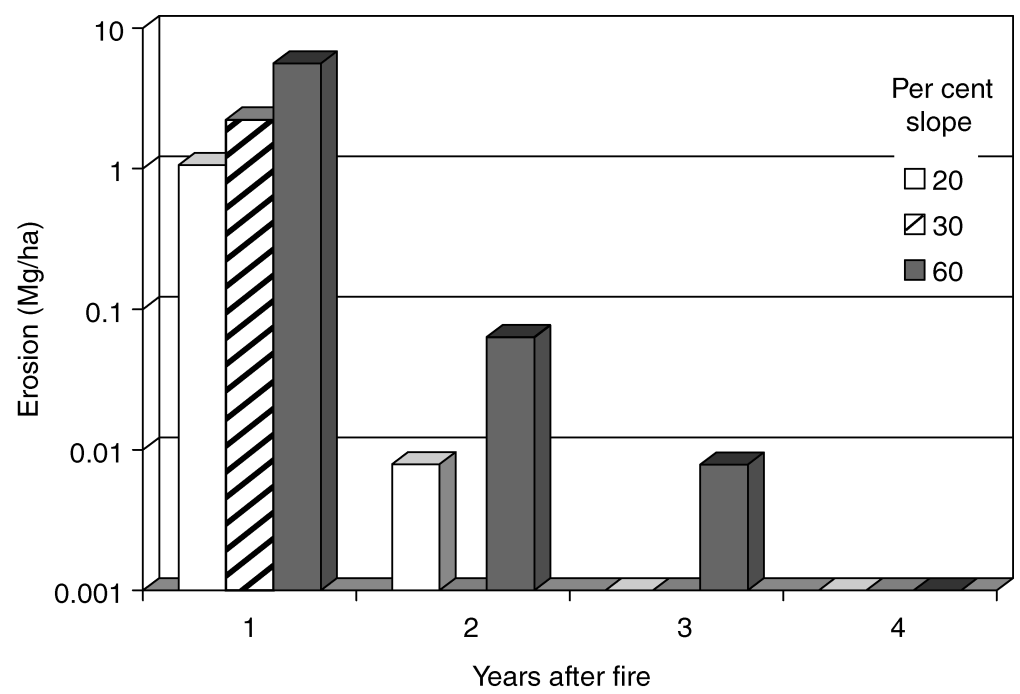

Fig. 17.1. Annual erosion rates measured following a wildfire in Eastern Oregon, for plots $25-40 \mathrm{~m}$ long with three different slopes for the first 4 years following a wildfire (adapted from Robichaud and Brown, 1999).

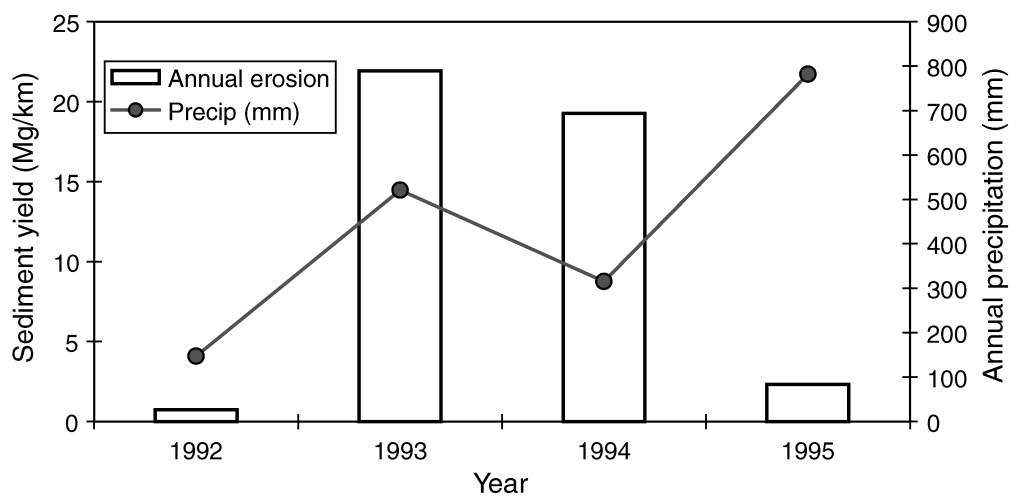

Fig. 17.2. Effect of weather and traffic on road sediment yields for a forest road in the Cascade Range in Oregon. Years 1992-1994 had traffic and 1995 had no traffic (based on Foltz, 1998). 
an order of a magnitude difference in annual erosion rates due to differences in precipitation between years 2 and 3 . In the final year of the study (1995), erosion rates were much less without traffic than in the previous 2 years, even though it was the wettest year of the study.

Eroded sediments are frequently deposited in stream channels where they may remain for years to decades, slowly moving through the stream system in response to high runoff events (Trimble, 1999). The attenuation of sediment in stream channels and its role in watershed processes increases the importance of the scale at which sedimentation is measured. Hillslope scales will show large variations in erosion rates as disturbed sites recover (Fig. 17.1). Watershed scale observations will tend to reflect decade to century trends in erosion rates, with large sedimentation events associated with infrequent watershed disturbances or flood events (e.g. McClelland et al., 1997; Kirchner et al., 2001). Both managers and the public tend to focus on erosion and sediment delivery occurring in the first year or two following a disturbance. They generally fail to consider the impacts of that sediment as it is transported through the watershed stream systems in the decades that follow.

\section{Erosion Prediction}

Prediction of soil erosion by water is a common practice for natural resource managers evaluating impacts of management activities on upland erosion and downstream water quality. Erosion prediction tools are used to evaluate different management practices and erosion control techniques. One of the prediction tools recently developed is the Water Erosion Prediction Project (WEPP) model (Flanagan and Livingston, 1995). The WEPP model is physically based, and is particularly suited to modelling common forest conditions. A set of input files describing forest conditions was developed for the model (Elliot and Hall, 1997) and later a user-friendly suite of Internet interfaces was developed (Elliot, 2004). Included with these interfaces is a database of typical forest soil and vegetation conditions. These databases are comprised of soil erodibility values determined from rainfall simulation and from natural rainfall events by scientists within the Rocky Mountain Research Station and elsewhere. Validation of the WEPP model to estimate erosion rates due to forest disturbances has been encouraging (Elliot and Foltz, 2001).

\section{Modelling Typical Management Scenarios}

The WEPP model Internet interfaces for forests (Elliot, 2004) were used to compare the estimated sediment yields from fuel management for wildfire for two different sites (Table 17.1): the Bitterroot Mountains in Western Montana, and the western slopes of the Cascade Mountains in Western Oregon. The assumptions for the

Table 17.1. Model inputs for two example erosion analyses using the WEPP model. Both total slope lengths were assumed to be $200 \mathrm{~m}$.

\begin{tabular}{lcr}
\hline Site & Bitterroot Range, Montana & Cascade Range, Oregon \\
\hline Annual precipitation (mm) & 1021 & 2640 \\
Wildfire cycle (years) & 40 & 200 \\
Thinning cycle (years) & 20 & 20 \\
Prescribed fire cycle (years) & 20 & 40 \\
Harvest frequency (years) & 80 & 60 \\
Slope steepness (\%) & 30 & 60 \\
Buffer width (m) & 30 & \\
Harvesting disturbance & & \\
$\quad$ assumptions & $85 \%$ cover on harvested area in year 1, & \\
Wildfire disturbance & increasing to 100\% in year 5 & \\
Road density & $45 \%$ cover in the year following the fire, & \\
& increasing to 100\% by year 10 & \\
\end{tabular}


Montana conditions were a relatively dry forest (average precipitation is $1021 \mathrm{~mm}$ ), a 40 -year fire cycle, an 80-year harvest cycle and 30\% slope steepness. The assumptions for the Oregon conditions (average precipitation is $2640 \mathrm{~mm}$ ) were a 200-year fire cycle, a 40-year harvest cycle and $60 \%$ slope steepness common on these less eroded mountains. Both scenarios assumed a $200-\mathrm{m}$ long slope. The two management scenarios were chosen to demonstrate the utility of the prediction tool and the erosion risks associated with fuel management and harvest activities. USDA Forest Service soil quality standards state that timber harvest, thinning and prescribed fire will expose a maximum of $15 \%$ mineral soil (Page-Dumroese et al., 2000), so these values were used for their respective runs.

For each of the disturbances, 50 years of typical climate were generated by the FS-WEPP interface, to give 50 possible erosion rates. The interface calculated the average erosion rates and the 5-year return period erosion rates. Runs were carried out for wildfire, prescribed fire, harvesting and thinning. The hillside impact for thinning was assumed the same as harvesting. All scenarios except wildfire assumed an undisturbed buffer. A buffer in this case refers to a strip of vegetation along either side of an ephemeral or perennial stream to reduce delivery of upland eroded sediments. Buffers frequently include much of the forest stream riparian zone. Buffer widths used for this exercise are noted in Table 17.1. In the years following each disturbance, the hillslope was modelled as sequentially recovering, as recommended in the online documentation (Elliot et al., 2002), for 5 years following thinning and prescribed fire, and 10 years following wildfire.

\section{Modelling Results}

The results from the two scenarios are presented in Fig. 17.3. Figure 17.3a illustrates the wetter climate in the Oregon Cascade Range and Fig. $17.3 \mathrm{~b}$ the drier climate in the Bitterroot Mountains in Montana. There are several striking features on these two figures. The erosion following wildfire is more than two orders of magnitude greater than before the fire, and more than a magnitude greater than following a major forest operation with a buffer. Also, the erosion rate in the Cascades is an order of magnitude greater than that in the Bitterroots.

Thinning occurs at a greater frequency in the wetter climate in the Cascades than in the Bitterroot Range (Fig. 17.3a), contributing to the higher overall erosion rate (Table 17.2). Figure $17.3 \mathrm{~b}$ shows that the erosion rate following a prescribed fire, assuming a $15 \%$ mineral soil exposure, is 15 times greater than the erosion rate following a harvest operation.

Table 17.3 presents the runoff predictions expected the year following each respective disturbance from rainfall, and from winter events which include snowmelt and combined rainfall and snowmelt events. Winter processes dominate in both climates, but account for a higher proportion of the total runoff in the Bitterroot climate.

Weather is highly variable year to year. If the year following a fire or other disturbance is drier than normal, sediment yields are low to none. If the year has some major runoffgenerating storms, then erosion rates will be high. Figure 17.3 only shows the average predicted sediment yields from 50 different years of weather patterns for each point. Table 17.4 shows the probability that the sediment yield will be non-zero in the year of disturbance, and the sediment yield average from 50 different years. Table 17.4 also shows the sediment yield that may occur if the year following the disturbance is the most erosive year in five.

Table 17.4 appears to have a mismatch of data at first glance because the 'average' sediment yields are greater than the greatest yields in 5 years for both harvest scenarios, and for the Bitterroot climate after fire. This is because in these scenarios the only time that sediment was delivered was from a small number of highly erosive years. Hence, the most erosive year in five did not generate any sediment in the Bitterroot climate following harvesting, and was not sufficiently erosive to generate as much sediment as a 50-year average, for the Cascade harvest results, and the Bitterroot wildfire results. Understanding the reliance of extreme events as the causes of hillslope erosion in forests is critical when interpreting erosion research studies, or erosion modelling results.

Compared to the Bitterroot Range, there is a much greater likelihood that there will be 
(a) Cascade Range, Oregon

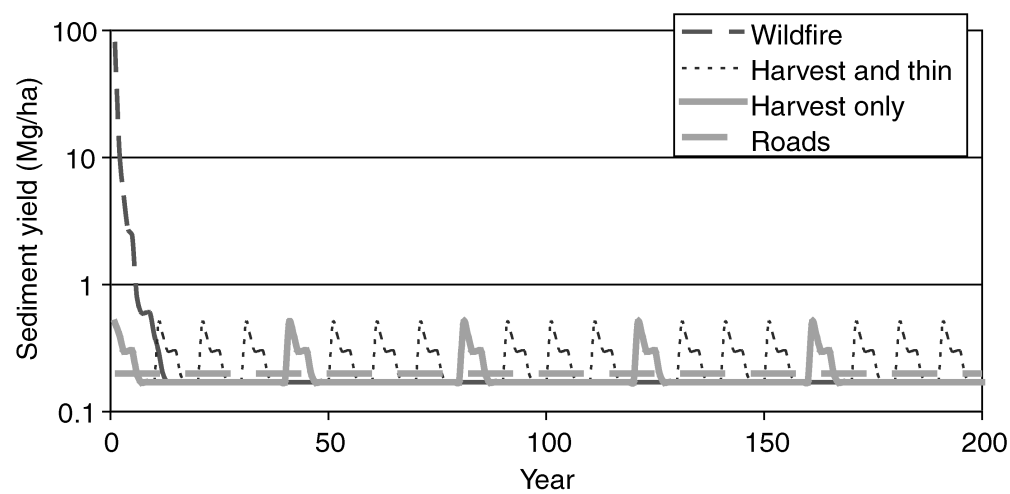

(b) Bitterroot Mountains, Montana

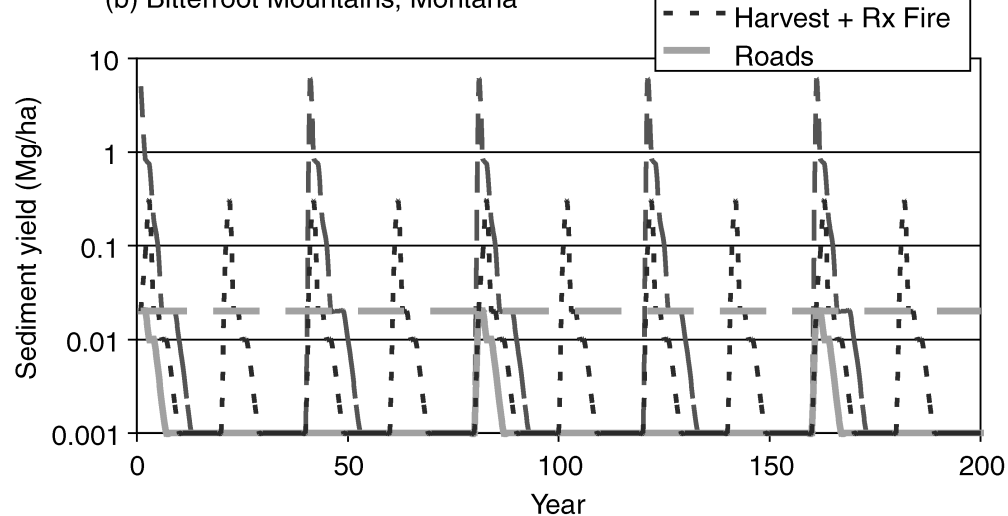

Fig. 17.3. Predicted annual hillslope sediment yield for an 'average' weather pattern vs year for different management conditions for the two scenarios described in Table 17.1 using the WEPP model.

Table 17.2. Predicted average annual sediment delivery rates over 200 years for the two scenarios presented in Table 17.1 and Fig. 17.3.

\begin{tabular}{lcc}
\hline & \multicolumn{2}{c}{ Average annual delivery during 200 years $(\mathrm{Mg} / \mathrm{ha})$} \\
\cline { 2 - 3 } & Bitterroot Range & Cascade Range \\
\hline Wildfire & 0.175 & 0.69 \\
Harvest only & 0.002 & 0.19 \\
Harvest with thinning & 0.004 & 0.27 \\
Harvest with prescribed fire & 0.023 & 0.28 \\
Roads with density of $4 \mathrm{~km} / \mathrm{km}^{2}$ & 0.02 & 0.2 \\
\hline
\end{tabular}

sediment delivered in the Cascade Range following a disturbance, and sediment delivery rates are much higher. In the Bitterroot Range, it was predicted that there is only a $6 \%$ chance of sediment delivery in the year following a forest operation (Table 17.4) following current federal guidelines to limit mineral soil exposure to only $15 \%$. Consequently, if a field study is 
Table 17.3. Predicted sources of runoff (rain or winter events) for 50 years of run for each of the disturbances for each climate.

\begin{tabular}{lcccrr}
\hline & \multicolumn{3}{c}{ Runoff in year following disturbance (mm) } \\
\cline { 2 - 3 } \cline { 5 - 6 } Disturbance & \multicolumn{2}{c}{ Bitterroot Range } & & \multicolumn{2}{c}{ Cascade Range } \\
\cline { 2 - 3 } \cline { 5 - 6 } Rain & Winter & & Rain & Winter \\
\hline Wildfire & 1.8 & 7.1 & & 23.8 & 56.5 \\
Harvest or thinning & 0.0 & 0.0 & & 0.1 & 1.1 \\
Prescribed fire & 0.1 & 0.1 & & 1.0 & 1.7 \\
\hline
\end{tabular}

Table 17.4. The average predicted sediment yields the year following a disturbance from 50 different annual weather sequences, and the erosion resulting from the most erosive year in five.

\begin{tabular}{lcc}
\hline & Bitterroot Range & Cascade Range \\
\hline Precipitation (mm) & & \\
Average & 1021 & 2640 \\
Greatest in 5 years & 1138 & 2868 \\
Sediment yield first year after harvest only & & 34 \\
Probability > $(\%)$ & 6 & 0.49 \\
Average (Mg/ha) & 0.02 & 0.14 \\
Greatest in 5 years (Mg/ha) & 0.0 & 100 \\
Sediment yield first year after wildfire & & 81 \\
Probability > 0 (\%) & 82 & 116 \\
Average (Mg/ha) & 4.98 & \\
Greatest in 5 years (Mg/ha) & 4.42 &
\end{tabular}

installed to measure sediment yields following a forest operation, there is only a $6 \%$ chance that any sediment will be collected, and a $94 \%$ chance that there will be no observed sediment yield. In the wetter and steeper Cascade Range scenario, there is a $34 \%$ chance of sediment delivery across a buffer in the year following harvesting or thinning.

Sediment yield from road networks depends on a number of watershed attributes, including climate, road design, construction methods and use, and topography. Elliot and Miller (2002) estimated road contributions (per $\mathrm{km}$ of road) for a wide range of western USA ecoregions. Table 17.2 provides an average estimate of road network sediment yields for the two sites, assuming a road density of $4 \mathrm{~km} / \mathrm{km}^{2}$. In the absence of traffic associated with fuel management, low-use roads are likely to yield only about $10-20 \%$ of the sediment expected from high-use roads. Table 17.2 and Fig. 17.3 both show the higher traffic road sediment rates, as most fuel reduction or harvesting scenarios will result in higher levels of traffic on much of a watershed's road network every year, assuming the watershed area is limited to about 5-10 km².

\section{Discussion}

On Fig. 17.3 and Tables 17.2-17.4, even though the difference in precipitation is only about a factor of 2.5 and the slope is twice as steep, the differences in runoff and erosion after the disturbance is more than ten times as great. Compared to the Cascade Range, a higher proportion of the runoff in the Bitterroot site is from winter processes (Table 17.3). Snow and snowmelt rates (typically $1 \mathrm{~mm} / \mathrm{h}$ ) are generally 
Table 17.5. Observed erosion rates following harvest and wildfire in or near the Bitterroot Range.

\begin{tabular}{lccc}
\hline & Year & Precipitation (mm) & Sediment yield (Mg/ha) \\
\hline $\begin{array}{l}\text { Sediment yield first year after harvest only } \\
\quad\end{array}$ & 1994 & & \\
$\quad$ Dry year & & 221 & 0.0 \\
Sediment yield first year after wildfire & 2001 & $599^{\mathrm{b}}$ & $0.5^{\mathrm{c}}$ \\
$\quad$ Below avg. precip. year & 2002 & $1036^{\mathrm{b}}$ & $10.0^{\mathrm{c}}$ \\
Above avg. precip. year & &
\end{tabular}

${ }^{a}$ Covert (2003); bUSDA-NRCS (2005); ' Elliot and Robichaud (2004).

much lower than rainfall intensities (typically up to $25 \mathrm{~mm} / \mathrm{h}$ ). These differences in amount and form of precipitation tend to bridge some of the thresholds that are common in erosion processes. Snowmelt rates are generally well below forest infiltration rates until soils are saturated. Low runoff rates from snowmelt or low intensity precipitation events frequently do not exceed critical shear values of forest soils, so erosion is limited to raindrop splash erosion. Hence, an increase in precipitation of 2.5 and the steeper slopes cause these types of threshold values to be exceeded at the hillslope scale, which causes the disproportionate increase in predicted erosion rates in Fig. 17.3 and Table 17.4.

The predicted results from the Bitterroot site can be compared to observed erosion rates from studies over the past 10 years. Table 17.5 shows the results from three separate studies, one after thinning and prescribed fire, with a dry year following, one after wildfire with a moderate year following, and one following a wildfire with a wet year following. The results in Table 17.5 support the WEPP model predictions presented in Table 17.4, with observed erosion rates well below average in dry years, and well above average in a wet year containing several high intensity summer storms (Elliot and Robichaud, 2004).

The magnitude of the results from the two climates presented in Fig. 17.3 and Tables 17.2-17.4 cannot be directly compared to each other because of the differences in climate, slope and management. What is apparent, however, is that the same principles of considering erosion following disturbances and frequencies of those disturbances are critical to the watershed planning process.

Results from this study suggest that using an average erosion rate may not accurately reflect the impacts of forest disturbances on watersheds, particularly when attempting to characterize watershed impacts over a short time period. Following a forest disturbance, the greatest amount of sediment is delivered in the first year, and after several years, delivery is below the level of detection. The amount of sediment delivered is highly dependent on the first year's climate. Eroded sediments following wildfire are not likely to be routed through the stream network for a number of years, or even decades. In the interim, sediments are stored in the alluvial deposits of forest streams. Watershed managers need to better understand risks associated with the different levels and temporal nature of sediment yields, and use that knowledge to develop forest management strategies, like timing and frequency of prescribed fire or thinning. Erosion from roads must be considered in any management strategy to estimate the total impact of management activities (Conroy, 2001; Elliot and Miller, 2002). As previously discussed, managers need to exercise caution when dealing with average values, as variability and outliers frequently dominate hydrologic processes.

The results of the modelling analysis presented in Fig. 17.3 and Tables 17.2-17.4 raise a number of important issues for further discussion on the impacts of timber harvest or fuel management on sediment movement in forested watersheds. Erosion following wildfire is much greater than erosion due to forestry operations, despite the higher frequency of such operations. Erosion from wildfire, however, is a natural phenomenon, which has driven the development of forest and associated stream ecosystems. Occasional high upland erosion rates and large sediment yields have played an important role in shaping landscapes and introducing fresh material into our stream systems 
(Kirchner et al., 2001). In the last century, scientists have concluded that fire was important for ecosystem health, and that fire exclusion has resulted in a decline of the health of many forests (Schmidt et al., 2002; Conard and Hilburner, 2003). Currently, scientists and forest managers are trying to determine if wildfire severity can be reduced with fuel management practices (Conard and Hilburner, 2003). If wildfire occurrence is reduced, will the large runoff and erosion events that follow lead to a decline in the health of hydrologic and aquatic ecosystems? A related question is: can erosion associated with severe wildfires be reduced with fuel management practices? These questions will require significant interdisciplinary research to increase understanding of the relationships among wildfire, fuel management and watershed health.

Forest roads contribute sediment to stream systems in most years, and in many years generate more sediment than forested hillsides (Fig. 17.3). Modelling results from this study assumed that forest operations may contribute low levels of sediment to stream systems more frequently than the natural wildfire cycle (Fig. 17.3). Sediment delivered from roads and forestry operations are likely to have a finer texture than sediment from wildfire. They are less likely to contribute cobbles to the stream beds that are preferred by many aquatic organisms. Further research is needed to evaluate the importance of large runoff events following fires for delivering coarse sediments to streams, while flushing fine-textured sediments through the stream system.

\section{Summary}

The WEPP model was used to compare sediment yields from forested hillslopes following wildfire to those from the same slopes following forestry operations. Sediment yields following forestry operations are much lower than those following wildfire in both the year following the disturbance and when averaged over two centuries. It is not known, however, if reducing large sediment yields that follow wildfire will result in improved watershed health in the long term.

Field work and modelling results lead to the following conclusions:

- Sediment delivery following forest operations and prescribed fire with forested buffers are an order of magnitude or more lower than following wildfire.

- Roads can generate a significant proportion of sediment in a forested watershed.

- Additional research is needed to determine long-term effects of fuel management practices on the occurrence and severity of wildfire, and on watershed health.

\section{References}

Conard, S. and Hilbruner, M. (2003) Influence of Forest Structure on Wildfire Behavior and the Severity of its Effects. USDA Forest Service, Washington, DC.

Conroy, W.J. (2001) Use of WEPP modeling in watershed analysis and timber harvest planning. Paper no. 01-8005. Presented at the American Society of Agricultural Engineers Annual International Meeting, 20 July-1 August, Sacramento, California. American Society of Agricultural Engineers, St Joseph, Michigan.

Covert, S.A. (2003) Accuracy assessment of WEPP-based erosion models on three small, harvested and burned forest watersheds. Unpublished MSc thesis. University of Idaho, Moscow, Idaho.

Elliot, W.J. (2004) WEPP Internet interfaces for forest erosion prediction. Journal of the American Water Resources Association 40, 299-309.

Elliot, W.J. and Foltz, M. (2001) Validation of the FSWEPP interfaces for forest roads and disturbances. Paper no. 01-8009. Presented at the American Society of Agricultural Engineers Annual International Meeting, 30 July-1 August, Sacramento, California. American Society of Agricultural Engineers, St Joseph, Michigan.

Elliot, W.J. and Hall, D.E. (1997) Water Erosion Prediction Project (WEPP) Forest Applications. General Technical Report INT-GTR-365. USDA Forest Service, Rocky Mountain Research Station, Ogden, Utah. 
Elliot, W.J. and Miller, I.S. (2002) Estimating erosion impacts from implementing the National Fire Plan. Paper no. 02-5011. Presented at the American Society of Agricultural Engineers Annual International Meeting, 28 July-31 July, Chicago, Illinois. American Society of Agricultural Engineers, St Joseph, Michigan.

Elliot, W.J. and Robichaud, P.R. (2004) The effectiveness of postfire mitigation treatments. Presented at the 2004 Burned Area Emergency Rehabilitation Training Workshop. April. Denver, Colorado.

Elliot, W.J., Hall, D.E. and Scheele, D.L. (2002) Disturbed WEPP: WEPP interface for disturbed forest and range runoff, erosion and sediment delivery. http://forest.moscowfsl.wsu.edu/fswepp/docs/distweppdoc.html (Accessed February 2004.)

Flanagan, D.C. and Livingston, S.J. (eds) (1995) WEPP User Summary. NSERL Report No. 11. USDA Agriculture Research Service, National Soil Erosion Research Laboratory, W. Lafayette, Indiana.

Foltz, R.B. (1998) Traffic and no-traffic on an aggregate surfaced road: sediment production differences. Proceedings of the Seminar on Environmentally Sound Forest Roads and Wood Transport, 17-22 June 1996. Food and Agriculture Organization, Rome.

Kirchner, J.W., Finkel, R.C., Riebe, C.S., Granger, D.E., Clayton, J.L., King, J.G. and Megahan, W.F. (2001) Mountain erosion over 10 yr, 10 k.y., and 10 m.y. time scales. Geology 29, 591-594.

McClelland, D.E., Foltz, R.B., Wilson, W.D., Heinemann, R., Cundy, T.W., Saurbier, J.A. and Schuster, R.L. (1997) Assessment of the 1995 and 1996 Floods and Landslides on the Clearwater National Forest. Region 1. USDA Forest Service, Missoula, Montana.

Page-Dumroese, D., Jurgensen, M., Elliot, W., Rice, T., Nesser, J., Collins, T. and Meurisse, R. (2000) Soil quality standards and guidelines for forest sustainability in northwestern North America. Forest Ecology and Management 138, 445-462.

Robichaud, P.R. and Brown, R.E. (1999) What happened after the smoke cleared: Onsite erosion rates after a wildfire in Eastern Oregon. (Revised) In: Olsen, D.S. and Potyondy, J.P. (eds) Proceedings AWRA Specialty Conference: Wildland Hydrology, Nov. 2000, Bozeman, Montana. AWRA, Herndon, Virginia, pp. 419-426.

Robichaud, P.R., Luce, C.H. and Brown, R.E. (1993) Variation among different surface conditions in timber harvest sites in the Southern Appalachians. In: Larionov, J.A. and Nearing, M.A. (eds) Proceedings from the Russia, U.S. and Ukraine International Workshop on Quantitative Assessment of Soil Erosion. Moscow, Russia, 20-24 September. The Center of Technology Transfer and Pollution Prevention, Purdue University, West Lafayette, Indiana, pp. 231-241.

Schmidt, K.M., Menakis, J.P., Hardy, C.C., Hann, W.J. and Bunnell, D.L. (2002) Development of Coarse-scale Spatial Data for Wildland Fire and Fuel Management. General Technical Report RMRS-GTR-87. US Department of Agriculture, Forest Service, Rocky Mountain Research Station, Fort Collins, Colorado.

Trimble, S.W. (1999) Decreased rates of alluvial sediment storage in the Coon Creek Basin, Wisconsin, 1975-1993. Science 285, 1244-1246.

USDA-NRCS (2005) Montana SNOTEL Sites. United States Dept. of Agriculture Natural Resource Conservation Service. http://www.wcc.nrcs.usda.gov/snotel/Montana/montana.html (Accessed February 2005.) 